\title{
Antibiotic Resistance and Plasmid Profiles of Bacteria Isolated from Abattoir Effluents around Ikpoba River in Benin City, Nigeria
}

\author{
*ATUANYA, EI; NWOGU, NA; ORAH, CU \\ Department Of Microbiology, University Of Benin, PMB 1154 Benin City, Edo State, Nigeria. \\ *Corresponding Author Email: ernest.atuanya@uniben.edu
}

\begin{abstract}
Abattoirs are known all over the world to pollute the environment either directly or indirectly from their various processes. The aim of this work is to determine the bacterial load, antibiotic resistance and plasmid profile of resistant bacteria isolated from government and private abattoirs around in Ikpoba River in Benin City. Bacteria and coliform count were done using pour plating method. The total viable bacteria counts ranged $4.2 \times 10^{5} \pm 1.8-1.5 \times 10^{6} \pm 0.7 \mathrm{cfu} / \mathrm{ml}$ and $1.3 \times 10^{6} \pm 0.1-3.1 \times 10^{6} \pm 0.5 \mathrm{cfu} / \mathrm{ml}$ for government and private abattoir respectively, The coliform count ranged from $2.7 \times 10^{5} \pm 0.1-3.8 \times 10^{5} \pm 1.4 \mathrm{cfu} / \mathrm{ml}$ and $5.5 \times 10^{5} \pm 0.3-9: 2 \times 10^{5} \pm 0.4 \mathrm{cfu} / \mathrm{ml}$ for government and private abattoir respectively. Escherichia coli, Streptococcus faecalis, Pseudomonas aeriginosa, Enterobacter aerogenes, Micrococcus luteus, Bacillus subtills and Staphylococcus aureuswere isolated and identified by cultural, morphological and biochemical characteristics. Susceptibility of the microbes was determined. The isolates were resistant to most of the commonly used antibiotics. Plasmid profile of isolates was also determined. The profile study shows that all resistant bacterial isolates harbored plasmid mediated resistance to antibiotics which was confirmed by plasmid curing. Therefore this research showed contamination of abattoirs effluents with antibiotic resistant bacterial isolates. This specially calls for treatment of the wastewater before discharging into the river.
\end{abstract}

\section{DOI: https://dx.doi.org/10.4314/jasem.v22i11.7}

Copyright: Copyright $(2018$ Atuanya et al. This is an open access article distributed under the Creative Commons Attribution License (CCL), which permits unrestricted use, distribution, and reproduction in any medium, provided the original work is properly cited.

Dates: Received: 18 September 2018; Revised: 26 October 2018; Accepted 12 November 2018

Keywords: Effluent, abattoir, antbiotic resistance, plasmid profiles

The abattoir industry is an important component of livestock industry in Nigeria providing domestic meat supply to over. 1.5 million people and employment opportunities for the teeming population (Nafarnda et al., 2012). Abattoirs are known all over the world to pollute the environment either directly or indirectly from their various processes. Quinn and Matarlare (1989) observed the effluent discharged from slaughter house has caused the deoxygenating of rivers. They has also been known to contaminate ground water (Coker et al., 2001.)Girards (2005) reported during a study that blood one of the major dissolved pollutants in slaughter effluent has a high chemical oxygen demand (COD). This impacts high organic pollutant on the recovering waters for oxygen within the ecosystem. Blood also contributed nitrogen content in the effluent. Wastewater from an abattoir is particularly concentrated sources of oxygen consumption waste (Girards, 2005). Disposal of abattoir waste may introduce enteric pathogens into surface and groundwater and the pathogen isolates from abattoir wastewater can' survive in the environment and pose danger to human and animals (Coker et al., 2001). Coker et al. (2001) shows that abattoir waste can affect water and land qualities if proper management practices are not followed. In Nigeria, many abattoir dispose their effluents directly into streams and rivers without any form of treatment and slaughter meat are washed by the same river water (Adelegon, 2002). Such is the situation in several private and government abattoir in most part of the country. . Pathogenic bacteria in humans and animals resistant to commonly used antibiotic have become a major global healthcare problem in the $21^{\text {st }}$ century. Nowadays, antibiotic resistant bacteria can be found in all different ecological niches. Selective pressure in favour of bacteria possessing these gene has emerged from the abusive use of antibiotics mainly in abattoir, agriculture and animal farming (Kummerer, 2004). Liquid and Solid waste from abattoir processing as well as human excretions has also led to dissemination of resistant bacteria in the environment. The flexibility of these bacteria has contributed to their survival in altered environments because of their capacity to acquire and transfer resistant genes. Bacteria has developed resistant to all different classes of antibiotics 
discovered to date. The most frequent types of resistant is acquired and transmitted horizontally either through conjugation, transformation or transduction of plasmid. Indiscriminate and inappropriate use of antibiotics in human and animal mediation has resolute in the simultaneous development of resistance to several antibiotic classes creating very dangerous multidrug resistance (MDR) bacterial strained. The widespread emergence of multidrug resistance among bacteria pathogen has become one of the most serious challenge in clinical therapy (Atuanya and Ogunleye, 2015)The incidence of MDR bacteria has increased during the last few years and has been documented worldwide from both the clinical and environmental samples (Kummerer, 2004).Research has also shown that there has been sigmoid rise in resistance over time in the presence of a constant of antibiotic consumption and a threshold level of antibiotics usage needed to trigger the emergence of resistance to significant levels (Austin el al, 1999). This study examined the antibiotic resistance and plasmid profiles of bacteria isolated from abattoir effluents around Ikpoba River in Benin City.

\section{MATERIAL AND METHODS}

Sample Collection: Four (4) liters of abattoir effluents were collected from two sampling point in both government owned and private owned abattoirs located along Ikpoba River. Ikpoba River is a fourth order stream located in Benin City, Edo State in SouthWestern Nigeria. (Lat. $6.5^{\circ} \mathrm{N}$, Longitude $5-8^{\circ} \mathrm{E}$ ). The Sterile plastic containers were aseptically used in drawing the effluent running off the drainage systems just as they were leaving slaughter houses. The samples were collected at 30days intervals for a period of four months from each abattoir and labeled appropriately. Samples for bacteriological and physicochemical analyses were collected in two sets of sterile plastic bottles. Samples for analyses of dissolved oxygen (DO) and biochemical oxygen demand (BOD) were collected separately oin presterilized brown glass bottles. The oxygen in the DO containers were fixed on site by adding $1.2 \mathrm{ml}$ each of Winkler's solution. Samples for other physicochemical analyses were collected in ethanol sterilized 2 liters plastic containers and were sent to the laboratory in ice-packed cooler. Those samples that could not be analyzed the same day were stored in a refrigerator at a temperature of $4^{\circ} \mathrm{C}$.

Bacteriological Analysis of Abattoir Effluents: The total heterotrophic and total coliform bacterial loads of effluent (waste-water) sample were determined using pour plate technique with molten nutrient and MacConkey agar at $35^{\circ} \mathrm{C}$ for $24 \mathrm{hrs}$ respectively as described by Cheesebrough (2000) and APHA (2005).Bacterial isolated were obtained were then purified into pure culture and identified based on their morphological, cultural and biochemical test Cheesebrough (2000)

Physicochemical Analysis of Collected Abattoir Wastewater Samples: Dissolved oxygen and biochemical oxygen demand (BODs) of effluent samples using the Azide method, a modified Winkler's method (APHA, 2005). The closed reflux titrimetric method was used for determination of chemical oxygen demand (COD). Total suspended solides (TSS) and total dissolved solid were determined using the gravimetric methods (APHA, (2005). The $\mathrm{pH}$ and conductivity were measured using pH-meter model 3020 of Jenway limited. The nitrate, phosphate, sulphate and heavy metal content of effluent samples were determined colorimetrically using the miltion ROY spectrnic 21D spectrophotometer. Lever of significance between varying data was determined using multi-samples comparison (Rheinhemer, 1991).

Antibiotic Susceptibility Testing: The agar diffusion technique as described by (Bauer et al, 1996) was used. The bacterial colonies from the pure culture were transferred into nutrient broth and incubated overnight. Thereafter, the test organisms were streaked on agar plates using sterile inoculating wire loop. The appropriate multi - disc depending on whether the test organism plated was a Gram negative organism or Gram positive organism was then placed firmly onto the surface of the dried plates, using sterile forceps. The plates were left at room temperature for one hour to allow diffusion of the different antibiotics from the disc into the medium. The plates were then incubated at $37^{\circ} \mathrm{c}$ for 18-24 hours. Interpretation of results was done using the zone sizes. Zone of inhibition of greater than $10 \mathrm{~mm}$ were considered sensitive, $5-10 \mathrm{~mm}$ moderate sensitive and non-zone of inhibition resistant

Plasmid Profile: Detection of plasmids among antibiotic isolates; plasmid analysis was performed on representative isolates selected on the basis of their antibiotic resistance phenotypes. The modified alkaline lyses method for plasmid extraction described by Opere and Ojo (2013) was used for extraction of plasmid

Extraction of plasmid: Organisms were grown in $2.5 \mathrm{ml}$ of nutrient broth and incubated at $37^{\circ} \mathrm{C}$ for $18 \mathrm{hrs}$. After incubation, $0.5 \mathrm{ml}$ of each culture was transferred into $1.5 \mathrm{ml}$ Eppendorf tubes for plasmid 
extraction and glycerol was added to the remaining cultured and stored at $4{ }^{\circ} \mathrm{C}$. The Eppendorf tubes .were centrifuged at $6,000 \mathrm{rev} / \mathrm{min}$ for 15 seconds after which the supernatant was carefully removed with the use of fine-tip automatic micropipette and the cell pellet was thoroughly suspended in the 100 ul of lysozyme solution. The pellet Olysozyme mixture was incubated at $0^{\circ} \mathrm{Cfor} 30 \mathrm{mins}$ after which $200 \mathrm{ml}$ of the alkaline sodium doedecyl sulphate (SDS) solution was added and gently vortexed. This suspension was almost clear and slightly viscous. The tube was maintained for $5 \mathrm{mins}$ at $0^{\circ} \mathrm{C}$ and then $150 \mathrm{uJ}$ of sodium acetate solution was added. The content of each tube was gently mixed for about six to seven seconds during which clots of DNA were observed in each tube, the tubes with high molecular weight RNA and chromosomal DNA showed precipitate. The tubes were centrifuged for 5 mins at $15,000 \mathrm{rev} /$ minute to yield a clear supernatant. About $0.4 \mathrm{ml}$ of the supernatant was removed from each tube and transferred into smaller centrifuge tubes. One milliliter of cold ethanol was added and held at $-20^{\circ} \mathrm{C}$ for 50 mins. The precipitate was then collected by centrifugation at $600 \mathrm{rev} / \mathrm{min}$ for 2 mins and the supernatant was removed by aspiration. The pellet was dissolved in $100 \mathrm{ul}$ of $0.1 \mathrm{M}$ sodium acetate/0.05 Tris $\mathrm{HCl}(\mathrm{pH} 8)$ and reprecipitated in 2 vols of cold ethanol. After 10 mins, at $-20^{\circ} \mathrm{C}$, the precipitate was again collected by centrifugation as described earlier. The pellet was dissolved in 40ul of water and then $10 \mathrm{ul}$ of sample buffer was added. Between 10-20ul of plasmid DNA in solution was applied to an agarose gel for electrophoresis.

Agarose Gel Electrophoresis: One percent agarose was prepared and loaded into electrophoresis chamber containing between 12 - 18 wells. The electrophoresis buffer that was used contained $40 \mathrm{mM}$ Tris, $20 \mathrm{mM}$ sodium acetate, $2 \mathrm{mM}$ EDTA, adjusted to $\mathrm{pH} 7.8$ with acetic acid. The sample buffer contained $25 \%$ sucrose, $5 \mathrm{mM}$ sodium acetate, $0.05 \%$ bromophenol blue and $0.1 \%$ SDS. Electrophoresis was allowed to proceed at room temperature until bands become visible at the positive end of the chamber. After electrophoresis, gels were stained with ethidium bromide $(1 \mathrm{ul} / \mathrm{ml})$ and viewed under UV Tran illumination. The molecular marker that was used was the bacterioiphage Hind III digest.

Plasmid Curing: The resistant isolates were cured with acridine orange to ascertain the involvement of plasmids in antibiotics resistance determination. A small inoculum of 100 to. $300 \mathrm{cfu} / \mathrm{ml}$ was added to acridine orange nutrient broth $(\mathrm{pH} 7.6)$ in varying concentration of acridine orange up to $0.25 \mathrm{mg} / \mathrm{ml}$ and incubated at $37^{\circ} \mathrm{C}$ for $24 \mathrm{~h}$. Cultures containing the highest concentration of acridine orange in which growth was clearly visible were diluted and spread on nutrient agar plates with appropriate antibiotics for susceptibility testing.

\section{RESULTS AND DISCUSSION}

The results of the bacterial profile of abattoir wastewater samples from Government and private abattoir in Benin City are summarized in Table 1 and 2. Total bacterial populations were found to be higher in Private abattoir wastewater than Government abattoir water. Escherichia coli, Streptococcus faecalis, Pseudomonas aeruginosa, Enterobacter aerogenes, Micrococcus luteus, Bacillus subtilis and Staphylococcus aureus were detected in all the wastewater samples. The bacteria occurrence frequency revealed that Escherichia coli was dominant in both abattoir samples while Streptococcus sp. was least abundant. Fecal coliforms live in the digestive tract of warm-blooded animals; their counts are often .used as a surrogate measurement for gastro-enteric pathogens, since the presence of fecal coliform bacteria is an indication of contamination by human and/or animal wastes. E. coli is the most prevalent member of the fecal coliform group; livestock harbour the bacteria and release it in their feces. And so the presence of E. coli in water is considered a specific indicator of fecal contamination and the presence of enteric pathogens; it is used as the general indicator organism that signals whether there has been fecal contamination or not. The high levels of total coliforms and E. coli in the abattoir wastewater are therefore an indication of the contamination of water sources with feacal material and possibly pathogenic organisms from abattoir wastewater discharged untreated; similar findings have early been reported (Janzen et al., 1974).The highly effective antibiotics to the isolates include amoxicillin and augumentin. The results show that susceptibility increased greatly after curing, which is the process of elimination of plasmid from host cells. High resistance of bacterial isolates in this study to amoxicillin, augumentin and cotrimoxazole corroborate the findings of Obi et al. (2004) who showed that at least $20 \%$ of bacterial isolates from water supply in rural Venda communities of South Africa demonstrated antibiotic resistance to cotrimoxazole, tetracycline, ampicillin, erythromycin and chloramphenicol. Again, in this study, differences were observed in the incidence of antibiotic resistance within the different stations. These differences may be attributed to the impact of human activities on the bacterial isolates within these stations (Abu and Egenonu, 2008). There are reports demonstrating the role played by industrial and human activities on the antibiotic resistance 
distribution of bacterial isolates in the environment (Kuyeli, 2007). Abu and Egenonu (2008) from their study on the current pollution status of the New Calabar River in the Niger Delta suggested that the antibiotic resistance patterns of bacterial isolates may be due to factors that are not linked to faecal pollution based on weak correlation between antibiotic resistance and faecal coliforms.

Table 1: Total heterotrophic bacterial and coliform bacteria count in Abattoir wastewater

\begin{tabular}{lllll}
\hline THC & & & CBC & \\
\hline Sample & $1^{\text {st }}$ batch & $2^{\text {nd }}$ batch & $1^{\text {s } b a t c h}$ & $2^{\text {nd }}$ batch \\
Analysis & analysis & analysis & analysis & Analysis \\
Mean & Mean & Mean & Mean & Mean \\
\hline Government Private & $.2 \times 10^{5} \pm 1.83 .1 \times 10^{6} \pm 0.5$ & $1.5 \times 10 \pm 0.71 .3 \times 10^{6} \pm 0.1$ & $2.7 \times 10^{5} \pm 0.15 .5 \times 10^{5} \pm 0.3$ & $3.8 \times 10 \pm 1.49 .2 \times 10^{5} \pm 0.4$ \\
\hline
\end{tabular}

$T H C=$ Total heterotrophic bacterial count $C B C=$ Coliform bacterial count

Table 2: Cultural, morphological and biochemical characteristics of the abattoir wastewater

\begin{tabular}{|c|c|c|c|c|c|c|c|}
\hline Characteristics & 1 &  & 3 & 4 & 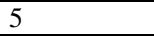 & 6 & 7 \\
\hline \multicolumn{8}{|l|}{ Cultural } \\
\hline Elevation & Low convex & Convex & Low convex & Low convex & Convex & Flat & Convex \\
\hline Margin & Entire & Smooth & Entire & Entire & Entire & Rough & Entire \\
\hline Colour & Cream & Whitish & Green & Cream & Yellow & Cream & Yellow \\
\hline Shape & Circular & Circular & Circular & Circular & Circular & Irregular & Circular \\
\hline Size & Small & Small & Medium & Medium & Medium & Large & Small \\
\hline \multicolumn{8}{|l|}{ Morphological } \\
\hline Gram staining & - & + & . & - & + & + & + \\
\hline Cell type & Rod & Cocci & Rod & Rod & Cocci & Rod & Cocci \\
\hline $\begin{array}{l}\text { Cell } \\
\text { arrangement }\end{array}$ & Single & Chains & Single & Single & Single & Chains & Cluster \\
\hline Spore staining & - & - & - & - & - & + & - \\
\hline \multicolumn{8}{|l|}{ Biochemical } \\
\hline Catalase & + & - & + & + & + & + & + \\
\hline Oxidase & - & - & + & - & - & - & - \\
\hline Coagulase & - & - & - & - & - & . & + \\
\hline Indole & + & - & - & - & - & - & - \\
\hline Urease & - & + & - & - & + & + & + \\
\hline Citrate & - & + & + & + & + & + & + \\
\hline \multicolumn{8}{|l|}{$\begin{array}{l}\text { Sugar } \\
\text { fermentation }\end{array}$} \\
\hline Glucose & + & + & + & + & + & + & + \\
\hline Lactose & + & - & - & + & - & - & . \\
\hline Possible isolates & Escherichia coli & $\begin{array}{l}\text { Streptococcus } \\
\text { faecalis }\end{array}$ & $\begin{array}{l}\text { Pseudomonas } \\
\text { aeruginosa }\end{array}$ & $\begin{array}{l}\text { Enterobacter } \\
\text { aerogenes }\end{array}$ & $\begin{array}{l}\text { Microcoocus } \\
\text { luteus }\end{array}$ & $\begin{array}{l}\text { Bacillus } \\
\text { subtilis }\end{array}$ & $\begin{array}{l}\text { Staphylococcus } \\
\text { aureus }\end{array}$ \\
\hline
\end{tabular}

Table 3: Zoneof inhibition (inmm) forantibiotic susceptibility test before curing

\begin{tabular}{|c|c|c|c|c|c|c|c|c|c|c|}
\hline G+ve PEF & $\mathbf{C N}$ & APX & $\mathbf{Z}$ & AM & $\mathbf{R}$ & CPX & $\mathbf{S}$ & SXT & $\mathbf{E}$ & \\
\hline Streptococcus & $10(\mathrm{R})$ & $0(\mathrm{R})$ & $15(\mathrm{I})$ & $0(\mathrm{R})$ & $18(\mathrm{~S})$ & $15(\mathrm{I})$ & $0(\mathrm{R})$ & $0(\mathrm{R})$ & 11 ( I ) & $0(\mathrm{R})$ \\
\hline Micrococcus & 16(1)" & $0(\mathrm{R})$ & $10(\mathrm{R})$ & $0(\mathrm{R})$ & $13(1)$ & $19(\mathrm{~S})$ & $0(\mathrm{R})$ & $0(\mathrm{R})$ & $18(\mathrm{~S})$ & $0(\mathrm{R})$ \\
\hline Bacillus & $\mathbf{O}(\mathbf{R})$ & $20(\mathrm{~S})$ & $0(\mathrm{R})$ & $0(\mathrm{R})$ & $0(\mathrm{R})$ & $0(\mathrm{R})$ & $18(\mathrm{~S})$ & $0(\mathrm{R})$ & $0(\mathrm{R})$ & $15(1)$ \\
\hline Staphylococcus & $0(\mathrm{R})$ & $18(\mathrm{~S})$ & $0(\mathrm{R})$ & $10(\mathrm{R})$ & $0(\mathrm{R})$ & $14(1)$ & $16(1)$ & $0(\mathrm{R})$ & $0(\mathrm{R})$ & $14(1)$ \\
\hline G-ve & SXT & CH & SP & CPX & $\mathrm{AM}$ & $\mathrm{AU}$ & PEF & OFX & $S$ & $\mathrm{CN}$ \\
\hline E.coli & $\mathbf{O}(\mathbf{R})$ & $0(\mathrm{R})$ & $0(\mathrm{R})$ & $13(1)$ & $0(\mathrm{R})$ & $0(\mathrm{R})$ & $0(\mathrm{R})$ & $22(\mathrm{~S})$ & $0(\mathrm{R})$ & $17(1)$ \\
\hline Enterobacter & $0(\mathrm{R})$ & $0(\mathrm{R})$ & $10(\mathrm{R})$ & $18(\mathrm{~S})$ & $0(\mathrm{R})$ & $0(\mathrm{R})$ & $10(\mathrm{R})$ & $20(\mathrm{~S})$ & $0(\mathrm{R})$ & $20(S)$ \\
\hline Pseudomonas & $0(\mathrm{R})$ & $0(\mathrm{R})$ & $0(\mathrm{R})$ & $15(1)$ & $0(\mathrm{R})$ & $0(\mathrm{R})$ & $0(\mathrm{R})$ & $18(\mathrm{~S})$ & $0(\mathrm{R})$ & $13(1)$ \\
\hline
\end{tabular}

Table 4: Zone of inhibition (in $\mathrm{mm}$ ) for antibiotic susceptibility test after curing

\begin{tabular}{|c|c|c|c|c|c|c|c|c|c|c|}
\hline G+ve & PEF & $\mathbf{C N}$ & APX & ZAM & $\mathbf{R}$ & CPX & $\mathbf{S}$ & SXT & $\mathbf{E}$ & \\
\hline Streptococcus & $12(1)$ & $18(\mathrm{~S})$ & $10(\mathrm{R})$ & $18(\mathrm{~S})$ & $10(\mathrm{R})$ & $20(\mathrm{~S})$ & $18(\mathrm{~S})$ & $11(1)$ & 08(R) & $19(\mathrm{~S})$ \\
\hline Micrococcus & $10(\mathrm{R})$ & $20(S)$ & $13(1)$ & ' $20(\mathrm{~S})$ & $14(1)$ & $18(\mathrm{R})$ & $22(\mathrm{~S})$ & $14(1)$ & $11(1)$ & $20(S)$ \\
\hline Bacillus & $10(\mathrm{R})$ & $24(\mathrm{~S})$ & $10(\mathrm{R})$ & $15(1)$ & $10(\mathrm{R})$ & $12(1)$ & $20(\mathrm{~S})$ & $10(\mathrm{R})$ & $13(1)$ & $18(\mathrm{~S})$ \\
\hline Staphylococcus & $14(1)$ & $20(S)$ & $10(\mathrm{R})$ & $16(S)$ & $18(\mathrm{~S})$ & $20(\mathrm{~S})$ & $25(\mathrm{~S})$ & $14(1)$ & $10(\mathrm{R})$ & $20(\mathrm{~S})$ \\
\hline G-ve & SXT & $\mathbf{C H}$ & SP & CPX & $\mathrm{AM}$ & $\mathrm{AU}$ & PEF & OFX & $\mathrm{S}$ & $\mathrm{CN}$ \\
\hline E-coli & $10(\mathrm{R})$ & $15(\mathrm{~S})$ & $18(\mathrm{~S})$ & $20(\mathrm{~S})$ & $10(\mathrm{R})$ & $10(\mathrm{R})$ & $14(1)$ & $28(\mathrm{~S})$ & $10(\mathrm{R})$ & $24(\mathrm{~S})$ \\
\hline Enterobacter & $13(1)$ & $18(\mathrm{~S})$ & $20(\mathrm{~S})$ & $22(\mathrm{~S})$ & $12(1)$ & $15(1)$ & $18(\mathrm{~S})$ & $26(S)$ & $14(1)$ & $23(\mathrm{~S})$ \\
\hline Pseudomonas & $10(\mathrm{R})$ & $10(\mathrm{R})$ & $14(1)$ & $18(\mathrm{~S})$ & $10(\mathrm{R})$ & $10(\mathrm{R})$ & $15(1)$ & $22(S)$ & $10(\mathrm{R})$ & $18(\mathrm{~S})$ \\
\hline
\end{tabular}


The plasmid profiles of seven bacterial isolates recovered from the government and private abattoir is presented in plate 1 . Plate 1 revealed detectable plasmid profiles in the bacterial isolates with band size ranging from 2067 to $10102 \mathrm{bp}$. Plasmid profiles have been reported to be useful in tracing the epidemiology of antibiotic resistance (Meyer, 1988). In this study, plasmid profiles were detected which indicates that plasmid profiling can also be used as an epidemiological tool for typing Escherichia coli, Pseudomonas aeruginosa and Staphylococcus aureus. as described by Meyer (1988). Son et al. (1998) stated that generally epidemiologically unrelated isolates contain different plasmid profiles whereas related isolates could also display variation in plasmid profiles. The more plasmids exist in an organism, the more specific is the plasmid profile as a marker for a single isolate. This may be true for isolates 3, 5, 6 and 7 which has two-three plasmid bands.

Table 5: Physicochemical analysis of abattoir wastewater

\begin{tabular}{|c|c|c|}
\hline Parameters & $\begin{array}{l}\text { Government } \pm \\
\text { S.E.M }\end{array}$ & $\begin{array}{l}\text { Private } \pm \\
\text { S.E.M }\end{array}$ \\
\hline $\mathrm{pH}$ & $6.25 \pm 0.5$ & $7.0 \pm 0.25$ \\
\hline Temperature $\left({ }^{\circ} \mathrm{C}\right)$ & $31.6 \pm 1.3$ & $32.0 \pm 1.2$ \\
\hline Conductivity (mhos $/ \mathrm{cm}$ ) & $75.6 \pm 31.3$ & $160.0 \pm 24.0$ \\
\hline Total solid (mg/L) & $933.8 \pm 118.5$ & $1261.9 \pm 211.6$ \\
\hline Turbidity (NTU) & $16.3 \pm 4.5$ & $19.8 \pm 1.7$ \\
\hline Allkalinity $(\mathrm{mg} / \mathrm{L})$ & $227.4 \pm 31.8$ & $508.4 \pm 28.1$ \\
\hline $\mathrm{DO}(\mathrm{mg} / \mathrm{L})$ & $4.45 \pm 0.8$ & $4.0 \pm 0.7$ \\
\hline $\mathrm{BOD}(\mathrm{mg} / \mathrm{L})$ & $100.7 .3 \pm 87.6$ & $1805.8 \pm 99.9$ \\
\hline $\operatorname{COD}(\mathrm{mg} / \mathrm{L})$ & $2871.8 \pm 166.4$ & $3528.6 \pm 237.3$ \\
\hline Sulphate $(\mathrm{mg} / \mathrm{L})$ & $160.2 \pm 34.2$ & $388.0 \pm 15.4$ \\
\hline Phosphate(mg L) & $4.2 \pm 1.4$ & $5.80 \pm 0.8$ \\
\hline Nitrate $(\mathrm{mg} / \mathrm{L})$ & $23.3 \pm 5.6$ & $38.3 \pm 1.20$ \\
\hline Chloride (mg/L) & $27.6 \pm 1.4$ & $47.3 \pm 8.8$ \\
\hline Heavy metals & & \\
\hline Ee(mgl) & $1.37 \pm 0.13$ & $1.52 \pm 0.16$ \\
\hline $\mathrm{Cu}(\mathrm{mg} / \mathrm{L})$ & $0.46 \pm 0.23$ & $0.53 \pm 0.28$ \\
\hline $\mathrm{Zn}(\mathrm{mg} / \mathrm{L})$ & $0.77 \pm 0.08$ & $1.03 \pm 0.24$ \\
\hline $\mathrm{Pb}(\mathrm{mg} / \mathrm{L})$ & $0.1 \pm 0.01$ & $0.01 \pm 0.003$ \\
\hline $\mathrm{Cd}(\mathrm{mg} / \mathrm{L})$ & $0.0042 \pm 0.0015$ & $0.007 \pm 0.003$ \\
\hline
\end{tabular}

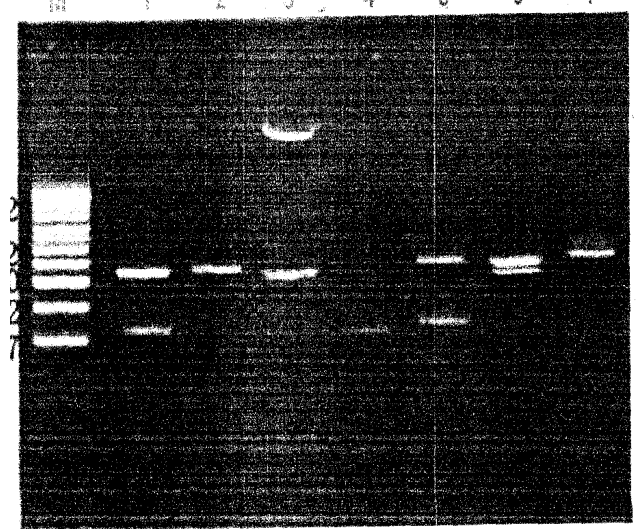

Plate 1: Plasmid profile of isolate in abattoir wastewater Lane 1: Escherichia coli, Lane 2: Streptococcus faecalis, Lane 3: Pseudomonas aeruginosa, Lane 4: Enterobacter aerogenes, Lane 5: Micrococcus lutevs, Lane 6: Bacillus subtilis, Lane 7: Staphylococcus aureus
The largest size of plasmid detected in all the plasmid positive isolates was $10102 \mathrm{bp}$. Bacterial antibiotics resistance patterns are sometimes associated with the presence of large plasmids and ability of plasmids for conjugation process (Alitheen et al., 2009). However, for other isolates that had no plasm-id, they also showed the multiple antibiotics resistance patterns with high number of antibiotics which indicates that resistance to most of these antibiotics is of chromosomal origin or on mobile genetic elements that may help in the dissemination of the resistant genes to other bacteria of human clinical significance (Son et al., 1998; Atuanya and Ogunleye, 2015).According to Carattoli (2003) and Yah et al. (2007), the antibiotic resistance in those isolates that seem not to possess plasmids was associated with chromosome and/or transposons instead of being plasmid-mediated. The $\mathrm{pH}$ of the abattoir wastewater ranged from $6.25 \pm 0.5$ $7.0 \pm 0.25$ for Government and Private abattoir respectively (Table 5). $\mathrm{pH}$ is the measure of acidity and alkalinity of water. However, the mean $\mathrm{pH}$ level of 6.7 - 7.2 was within the WHO tolerance limits of 6.0-9.0 for the discharged ofwastewater from all industries into river. (WHO, 1996) The level of temperature in the abattoir wastewater ranged from $31.6 \pm 1.3$ $32.0 \pm 1.2^{\circ} \mathrm{C}$. The conductivity levels in the wastewater sample ranged from $75.6 \pm 31.3-160.0 \pm 24.0$ mhos $/ \mathrm{cm}$. The mean value of $320 \mathrm{~cm}^{11}$ was within the tolerance limit. Similarly, turbidity values ranged from $16.3 \pm 4.5-19.8 \pm 1.7$ NTU (Table 5). The mean value of turbidity in the effluent samples was higher than the WHO guideline of 5 NTU for the discharged of wastewater into river or stream. The levels of chloride in the wastewater sample ranged from 27.6 \pm 1.4 $47.3 \pm 8.8 \mathrm{mg} / 1$ (Table 5). The concentration of nitrate ranged from $23.3 \pm 5.6-38.3 \pm 1.20 \mathrm{mg} / 1 ; 160.2 \pm$ $34.2-388.0 \pm 15.4 \mathrm{mg} / \mathrm{l}$ sulphate and $2.78-6.65 \mathrm{mg} / \mathrm{l}$ phosphate. The levels of nitrate in the abattoir wastewater may give rise to methaemoglobinemia, also the levels of nitrate reported in this study in addition to phosphate levels can cause eutrophication and may pose a problem if discharged into river or stream. Dissolved oxygen (DO) values obtained from the abattoir wastewater ranged between $4.0 \pm 0.7-4.45 \pm$ $0.8 \mathrm{mg} / 1$ (Table 5). DO is a measure of the degree of pollution by organic matter, the destructive of organic substances as well as the self-purification capacity of the water body

Conclusion: The results of this present study showed that abattoir wastewater contains high bacterial counts above the recommended level for discharge into water bodies in Nigeria. Most isolates in this study were resistant to septrin, streptomycin amoxillicin, augumentin and chloramphenicol but higher sensitivity was shown towards oflaxicin, gentamicin and 
ciprofloxacin. It is expected that oflaxicin, gentamicin and ciprofloxacin can be the drug of choice for effective management of disease caused by such bacteria. Multiple antibiotic resistant bacteria also occurred in microorganisms in the various abattoir wastewater samples. In addition, the study also revealed that curing of the plasmid increased susceptibility (sensitivity) to the test antibiotics although, resistance was still observed. The study also revealed that the isolates possess plasmids of various sizes.

\section{REFERENCES}

Abu, G O; Egenonu, C (2008). The current pollution studies of the new Calabar River in Niger Delta region of Southern Nigeria: A survey of antibiogram profiles of its bacterial isolates. Afr.

J. Environ. Sci. Technol. 2:134-141

Adelegen, J A (2002). Environmental policy and slaughter-house waste in Nigeria. In the proceeding of the $28^{\text {th }}$ WEDC conference kolkaa (Calcutta), India. 36pp.

Ademyemi, G; Adeyemo, O K (2007). Waste management practices at the Bodija abattoir, Nigeria. Intl. Jour. Environ. 64 (1): 71-82.

Alitheen, N R; Zulkifile, Y; Raba, A.R;Yeap, S K (2009) Antibiotic resistance and plasmid profiling OF Vibro paraheamolyticus isolated from cockles in padarg. Indonesian Intl. Food Res. Jour. $16: 53.58$

American Public Health Association (APHA) (2005) Standard method for the Examination of Water and Wastewater $21^{\text {st }}$ edition. American Public Health Association, Washington, D.C.

Amiisu, K O; Coker, A O; On, S L;Isokpehi, R D (2003)Arcobacterbutzlieri stains from poultry abattoir effluent in Nigeria. East Afri. Med. Jour. 80:218-221

Atuanya, E I; Nwogu, N A;Akpor, E A (2012). Effluent qualities of government and private abattoirs and their effect on Ikpoba River, Benin City, Edo State, Nigeria. Adv. Biol. Res.6(5): 196201

Atuanya, E I; Ogunleye, A (2015). Antibiotic resistance and plasmid profile of bacterial pathognes isolated from hair-dressing saloon effuents in Benin City. Nig. Jour. Life Sci. 5(1):80-92.

Austin, D.J; Kirstinsson, K G;Anderson, R M (1999).
The relationship between the volume of antimicrobial consumption in human communtities and the frequency of resistance. Procesdings of the National Academy of Sciences. New York 1156pp.

Baver, A W; Kirby, W M; Sherries, J C; Andturck, M (1996). Antibiotic susceptibility testing by a standardized single disc methods. American Jour. Clin. Path. 45:493-496.

Caraholi, A (2003). Plasmid-mediated antimicrobial resistance in Salmonella enteric Curr. Issues Mol. Biol. 113-122.

Chesssebrogh, M (2006). District Laboratory Practice in Tropical Countries. Part 2. Low Price Edition Cambridge univ. press, London 425pp.

Coker, A O; Olugosa, B O;Adeyemi, A O (2001). Abattoir efffuent quality in South Western Nigeria. The Processdings of the $27^{\text {th }}$ UNEDC Conference. (Lusaka, Zambia. 332pp.

Girard, J. (2005) Principles of Environmental Chemistry Jones and Bartleleft, usa. 216pp.

Hinton, M H; Medad, G C; Rowlimgs, C (2000). Microbiology control in meat industry. Flair Flow Europe technical Manual. 10:4-12.

Janzen, JJ; Bodine, A B; Luszoz, L.I (1975). A survey of effects of animal wastes on streat pollution from selected dairy farms. Jour. Dairy Sci.57: 260-263.

Kummerer, K (2004).Resistance in the environment, A review. Jour of Antimcrobial Agents Chemotherapy 54:311-320.

Kuyeli, M S (2007). Assessment of industrial effluent and their impact on water quality of stream in Blantype, Unima Zambia. 89pp.

Meyer, I W (1988). Use of plasmid profiles in epidemiological surveillance of disease outbreaks and tracing the transmission of antibiotics resistance. Clin. Microbiol. Review 1:228-243.

Nafarinda, W D; Ayayi, I E; Shawulu, J C; Kawe, M S; Omeiza, G.K (2012). Bacteriological quality of abattoir effluents discharged into water bodies in Abuja, Nigeria. Vert. Sci.12:55-59.

Obi, C L; Bessong, P O; Momba, M N; Potgieter, N; Samie, A; Igumbor, E O (2004). Profiles of 
antibiotic susceptibilities of bacterial isolateds and physico-chemical quality of water supply in rural venda communities. South Afr. Wat Res 30:515-519.

Opera, B O;Ojo, J O (2013). Antibiotic susceptibility and plasmid profile of pathogenic bacteria isolated from environmental surface in public toilet. Translat. J. Sci. Tech.3. (2):22-30.

Quinn, J M;Mafarlane, P N (1989). Effects of slaughter house and diary factory effluent on epilithon Wat. Rese. 28:1267-1273.

Son, R; Nasreldiin, E H; Zaiton, H; Samuel, L; Rusul, G; Nimita, F. (1998). Characterization of Vibro vulnificus isolated from cockles (Anadara granosa) antimicrobial resistance plasmid profiles and random amplification of polymorphic DNA analysis FEMS Microbiol. Letter 165:139143

World Health Organization (WHO) (1996). Water Quality Assessments- A Guide to use of Biota, Sediments and water in Environmental Monitoring WHO, Geneva Switzerland 17pp

Yah, C S; Chineye, H U; Eghafona, N O (2007). Multibiotics resistance plasmid profile of entric pathogens in paediatric patients from Nigeria. Biokemistri 19:35-42 